\title{
Patient Safety: An Injectable Education
}

\author{
Arnold William Klein \\ Geffen School of Medicine, University of California, Los Angeles, USA. \\ Email: awkleinmd@aol.com
}

Received April $7^{\text {th }}$, 2013; revised May $6^{\text {th }}, 2013$; accepted May $15^{\text {th }}, 2013$

Copyright (C 2013 Arnold William Klein. This is an open access article distributed under the Creative Commons Attribution License, which permits unrestricted use, distribution, and reproduction in any medium, provided the original work is properly cited.

\begin{abstract}
Until recently, the effects of all injectable filling agents were temporary and very rarely associated with permanent problems. In the past, the permanent injectable silicone had been used but had been so problematic that the Justice Department filed injunctions against certain physicians on behalf of the FDA. After 2000 a dangerous pattern grew in the corridors of Washington DC, where politics and money changed the face of America and the field of aesthetics to the detriment of the faces of the consumers. Industry has accomplished the approval of synthetic agents that should have never reached the market. Once injected under skin, the body cannot digest these agents and the immune system walls them off with resultant formation of nodules, which at times require surgical removal.
\end{abstract}

Keywords: Fillers; Sculptra; Artefill; Artecoll; Safety; Injectables

\section{Introduction}

In 2011, next to Botox, injectable fillers became the most popular cosmetic procedure in the United States [1]. Having been the physician responsible for the Black Box warning on Botox both the public and physicians are frequently unaware of the safety profile of certain injectables [2]. Neither the FDA and the medical literature, nor the beauty magazines provide adequate information concerning the problematic nature of certain fillers.

The cosmetic literature in the United States is largely written by physicians who are supported by Big Pharma and there is little written about adverse reactions to injectable agents for soft tissue. This is not the case in the United Kingdom [1]. Plastic surgeons in Britain in November of 2012 reported a dramatic rise in botched skin filler procedures leaving women with lifelong disfigurement. Some 70 percent of Britain's plastic surgeons have seen patients with problems resulting from temporary skin fillers. In addition, half of surgeons reported seeing patients with more serious complications from permanent fillers or semi-permanent fillers. Of these, 84 percent required corrective surgery or were deemed untreatable due to permanent damage [1].

\section{Reactions to Fillers}

While injection technique is important what happens under the skin once injected is far more critical. What you seek to avoid at all costs is an immunologic or allergic reaction to the implanted substance. Such reactions can cause large lumps that at times can be so severe they can result in facial deformity [3-5]. The popularity of fillers for facial restoration has seen the approval of various injectable agents by the FDA which should have never seen the light of day [2,3]. In the past, the permanent injectable silicone had been used but had been so problematic that the Justice Department filed injunctions against certain physicians on behalf of the FDA [2]. After 2000 a dangerous pattern grew in the corridors of Washington DC, where politics and money changed the face of America and the field of aesthetics to the detriment of the faces of the consumers.

\section{Maintaining Integrity vs. Big Pharma}

Industry and greed has accomplished the approval of synthetic agents which should have never reached the market. Once injected under skin the body cannot digest these agents and the immune system walls them off with resultant formation of nodules, which at times require surgical removal $[3,5,6]$. One such product that was approved was Artefill $^{\circledR}$ also known as Artecoll $^{\circledR}$. This product is polymethylmethacrylate which is a form of injectable Plexiglas beads. This product has long been associated in the worldwide dermatologic literature with scarring, and disfigurement only amenable to correction 
by surgery or at times steroid/5 fu injections sometimes. At present, Artecoll ${ }^{\circledR}$, the predecessor of Artefill ${ }^{\circledR}$, is no longer available in Canada. Furthermore both Germany and Switzerland have already advised physicians not to use this product $[2,3]$.

\section{The System of Trust Is Broken}

We know from the experience of Artecoll ${ }^{\circledR}$ in Canada that pharmaceutical companies cannot be relied upon to report adverse events to authorities, yet the FDA claims that it can evaluate adverse reactions by relying on doctors and "Big Pharma" to report these directly to the FDA. Furthermore, merely changing the name of the product (e.g. Artecoll ${ }^{\circledR}$ to Artefill $^{\circledR}$ ) doesn't change the history or adverse experiences of the past. In the literature, consultants have used the names interchangeably [2,3]. Furthermore, if Artefill ${ }^{\circledR}$ is new and improved, how can one gain FDA approval of Artefill ${ }^{\circledR}$ by studying Artecoll $^{\circledR}$.

\section{Artecoll/Artefill ${ }^{\circledR}$}

The purpose of the FDA is to protect the public interest in safety and efficacy of all medical products. Prior to the release of Artefill ${ }^{\circledR}$ in the USA, a senior member of the FDA was contacted with articles regarding the foreign experience with Artecoll. This did not prevent release of this product. Subsequently an article in the "Wall Street Journal" revealing the seriousness of adverse reactions to Artefill ${ }^{\circledR}$ helped cause the parent company to go into bankruptcy [7]. Recently Suneva Medicial Inc. San Diego, CA has brought this product back to market and as expected numerous adverse reactions have been seen. What follows are just a few of the cases I have recently seen [8].

\subsection{Case 1: Vision Loss}

D.S. is a 33 y.o. female actress on a well known television show. On $1 / 29 / 13$ she had a minor cosmetic procedure on her lip. While under anesthesia, her plastic surgeon injected Artefill in the depressions under her eyes. As soon as she awoke she could not see. She told the nurse who brushed her aside. She went home and spoke to her surgeon the next day. She was highly anxious and she had almost totally lost vision in her left eye. Subsequently she has seen three retinal specialists who have concluded that the Artefill occluded the blood supply to her left retina. Presently she has lost total vision in her left eye.

\subsection{Case 2: Partial Recovery}

LL is a 49 y.o. homemaker who had injections of Artefill 6 months before she was seen by my office. In the month prior to being seen she developed intermittent swelling around every site where the Artefill was implanted. She has refused to leave her house. After a series of precise injections of cortisone and an anticancer drug $5 f u$ into the sites she is currently $80 \%$ better.

\section{Sculptra}

Initially Sculptra received FDA approval for treatment of HIV associated fat loss in the face. This was a critical indication in that this condition had essentially become the Scarlet Letter of the 90's and was in need of a method of cosmetic management. It has now been approved for individuals without HIV who are seeking cosmetic enhancement. Daily calls and emails to my office are received from men and women who have had severe problematic reactions to Sculptra $[4,7]$.

\subsection{Case 1: Nasiolabial Folds}

DP is a 45 y.o. female who 11 months prior to being seen had undergone a series of three monthly injections of Sculptra to the cheeks, nasolabial folds, and periorbital areas. By the third visit she developed severe swelling in the periorbital area and refused further treatment. She had seen multiple physicians for this swelling and discoloration and received intralesional steroid injections which provided little improvement [9-11].

Most recently she saw a physician who suggested excision. When seen she had 3 - 4 nodules $(>10 \mathrm{~mm})$ in the inferior periorbital area and 2 on her right nasolabial fold (Figure 1) It was decided to use intralesional injectable 5 fu (5 parts) mixed with one part Kenalog $10 \mathrm{mg} / \mathrm{cc}$ with an excellent response. However, in long standing cases it may not work.

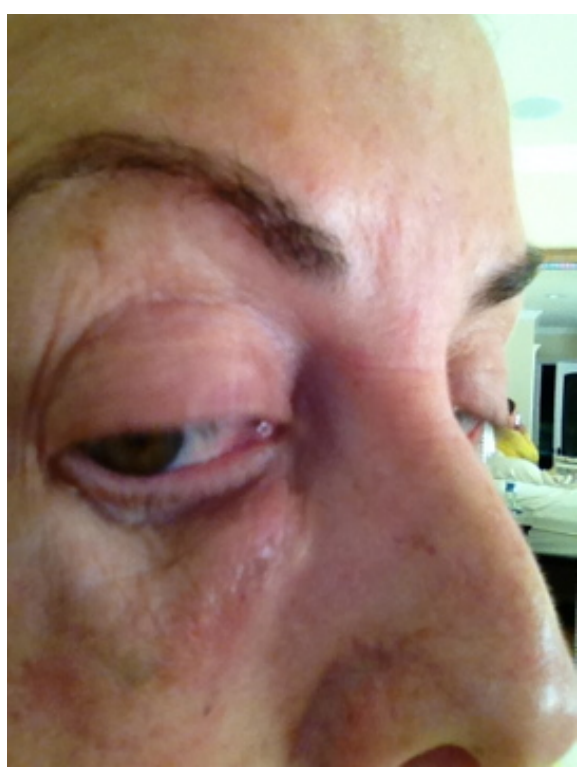

Figure 1. Suborbital Sculptra reaction. 


\subsection{Case 2: Internet Posting}

MK is a 38 y.o. female: in a letter she wrote, "I don't really need to see Dr. Klein but I want to really thank you to him for his stance on Sculptra in Real Self. I was just released from the hospital 3 weeks ago and nearly lost my life [5,10-13] it, until now [5]. I had a deep neck infection or abscess that was linked back to Sculptra. I had a touch up 3 weeks prior to getting sick. I had a surgery to put a drain in my neck and was given antibiotics, 24 hours later my airway was closing again and the infection was spreading. The doctors couldn't understand why it was still spreading. I had a 2nd surgery to place more neck drains, intubated and put in ICU. My daughter was looking into all the case studies for Sculptra and found out that the staph and strep biofilm infections are methicillin resistant. I ended with a total of six drains. I spent a total of 16 days in the hospital, 8 in the ICU and came home on $4 \mathrm{IV}$ antibiotics and all the drains in place. It has been a few weeks with all the drains removed and off all meds. I am grateful to be alive and I respect what you are telling people because it is true. You Dr. Klein saved my Life. I don't want to see anyone have to go through what I just endured and what my husband and daughters went through. I feel that the makers of Sculptra are hiding facts and it has everything to do with money. Again, I just wanted to express my thanks to you for being honest and taking a stand. You are a lifesaver $[5,10]$.”

\section{Some Common Mistakes}

Sculptra is an injectable agent that supposedly induces the formation of new collagen. However the FDA has never evaluated the fate of this injectable once implanted. Should not a biopsy be required for an agent's approval? Contrary to what the company suggests from biopsies of reactions it is an "immunologic foreign body reaction" that is noted after implantation. At times this reaction will fill volume but at others many lumps are seen. In the initial studies for HIV facial fat loss in the USA nodules were visual and palpable in many individuals in these trials. 52 percent were seen in the VEGA study, and 31 percent in the C \& W study. The average on-set was up to 218 days, with a range from 9 to 748 . Scuptra has been now been approved for immunocopetent individuals. For this study every single investigator was a paid consultant for the manufacturer of Sculptra and no biopsies were performed. This indicates how seriously inadequately cosmetic devices are evaluated by the FDA prior to their release. Large nodules have been seen above the lips, in the cheeks, under the eye and elsewhere in countless patients [4-7,12-15].

Prior to its approval in the USA a European literature did exist on the problems with Sculptra. In a series of 100 patients treated, 5 cases of infection, 12 cases of granuloma and 3 cases of long term allergic reactions were noted (Aesth Surgery). These reactions must be reported by affected individuals directly to the FDA.

In 2013, the manufacturers of fillers underwrite the costs of large conventions, travel, exotic vacations, and CME courses to the tune of a billion dollars annually. This behavior is ram-pant in the world of facial aesthetics. So please be cautious of what you put in your face or as an injector in your patient's faces. Please read as much as you possibly can before you let anyone put a needle in your face $[2,6,7,10]$.

\section{Acknowledgements}

P.S.C Thank you.

\section{REFERENCES}

[1] Doctors Warning Facial Fillers. http://www.theguardian.com/lifeandstyle/2012/jan/07/doc tors-warning-facial-fillers

[2] A. W. Klein, “Avoiding Adverse Events with Fillers: Fat, Collagen, Radiance, Silicone, Restylane, Artecoll: Letter to the Editor," Cosmetic Surgery Times, Vol. 6, No. 6, 2003, p. 3.

[3] A. W. Klein, "Reluctant to Use Artecoll: Letter to the Editor,” Skin \& Allergy News, Rockville, 2002, p. 16.

[4] B. Azizzadeh and M. Graivier, "Injectable Poly-L-Lactic Acid (Sculptra): Technical Considerations in Soft-Tissue Contouring," Plastic and Reconstructive Surgery, Vol. 118, Suppl. 3, 2006, pp. 55S-63S. http://dx.doi.org/10.1097/01.prs.0000234612.20611.5a

[5] A. W. Klein, "The Whole Truth Please-Sculptra Review -RealSelf,” 2009.

http://www.realself.com/review/the-whole-truth-please

[6] A. W. Klein, "Soft Tissue Augmentation 2006: Filler Fantasy,” Dermatologic Therapy, Vol. 19, No. 3, 2006, pp. 129-133. http://dx.doi.org/10.1111/j.1529-8019.2006.00066.x

[7] R. Rundle, “Things Get Ugly over a Beauty InjectionWSJ."

http://online.wsj.com/news/articles/SB118834446251311 594

[8] J. Alijotas-Reig, V. Garcia-Gimenez and M. VilardellTarres, "Late-Onset Immune-Mediated Adverse Effects after Poly-L-Lactic Acid Injection in Non-HIV Patients: Clinical Findings and Long-Term Follow-Up,” Dermatology, Vol. 219, No. 4, 2009, pp. 303-308. http://dx.doi.org/10.1159/000243804

[9] A. W. Klein, "Sculptra: An Injectable Disaster.” www.arnoldwklein.com/?p=978

[10] C. M. Burgess and R. M. Quiroga, "Assessment of the Safety and Efficacy of Poly-L-Lactic Acid for the Treatment of HIV-Associated Facial Lipoatrophy," Journal of the American Academy of Dermatology, Vol. 52, No. 2, 2005, pp. 233-239.

http://dx.doi.org/10.1016/j.jaad.2004.08.056 
[11] A. Klein, "Filler Follies, Huffington Post,” 2010. http://www.huffingtonpost.com/arnold-william-klein/fille r-follies_b_410987.html

[12] Apr 23, 2012-Dear Dr. Klein Disaster: I Was Injected Sculptra First Time in May 2009 (3 Series) in Cheek Hollows, Temples and Neck. I Had Excelent Subtle Results, ...What Do About Sculptra (NewFill) Lumps and Granulomas Doctor... www.realself.com/review/the-whole-truth-please

[13] A. W. Klein, "What Do about Sculptra (NewFill) Lumps and Granulomas.”

http://www.realself.com/question/what-can-do-about-scul ptra-lumps

[14] A. W. Klein, "Substances for Soft Tissue Augmentation," In: I. Freedberg, Ed., Fitzpatrick's Dermatology in General Medicine, 6th Edition, McGraw Hill, New York, 2003.

[15] A. W. Klein and B. W. Ayers, "Lip Augmentation,” In: S. J. Aston, Ed., Aesthetic Plastic Surgery, Elsevier BV, Amsterdam, 2009, pp. 855-860. 